\title{
ESTUDO SOROLÓGICO SOBRE A CEPA A/New Jersey/8/76 EM GRUPOS POPULACIONAIS BRASILEIROS
}

\author{
Nota PRÉvia
}

J. A. N. Candeias*

M. L. Rácz*

S. O. Oliveira **

\begin{abstract}
RSPU-B/32

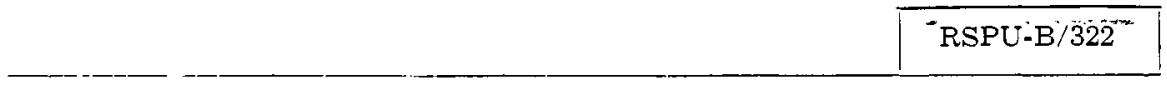

Candeias, J.A.N. et al. - Estudo sorológico sobre a cepa A/New Jersey/8/76 $\epsilon m$ grupos populacionais brasileiros (nota prévia). Rev. Saúde públ., S. Paulo, 10:269-70, 1976.

REsumo: O estudo sorológico de vários grupos populacionais brasileiros, pela pesquisa de anticorpos inibidores da hemaglutinação para a cepa de virus da influenza $A / N \in w$ Jersey/8/76, deu os seguintes resultados preliminares: $7,8 \%$ do total de criancas normais e $75 \%$ do total de individuos adultos normais já estudados mostraram possuir títulos de anticorpos inibidores da hemaglutinação para aquela cepa $\geqslant 80$; num grupo de indios da região do Xingú, todos os soros testados apresentaram titulo $<40$.
\end{abstract}

UNitermos: Influenza, virus A/New Jersey/8/76. Sorologia.

\section{N T RODUCAO}

O comportamento epidemiológico da influenza pode ser avaliado pela análise adequada de uma multiplicidade de dados, desde os baseados no isolamento do agente etiológico, ou em levantamentos sorológicos, até os dados de mortalidade, morbidade e absentismo.

No que diz respeito aos levantamentos sorológicos, a pesquisa de anticorpos inibidores da hemaglutinação tem-se mostrado de particular utilidade, pela simplicidade de execução e pela demonstrada correlação entre os níveis pre-epidêmicos des- tes anticorpos e a resistência à infecção ${ }^{1, ",}, 3$.

0 presente trabalho, em fase preliminar, tem o objetivo de evidenciar o aparecimento da cepa A/New Jersey/8/76 em diversos grupos da população brasileira.

\section{MATERIAL E METODOS}

Estão sendo estudados os seguintes grupos populacionais: 200 crianças normais

* Do Departamento de Microbiologia e Imunologia do Instituto de Ciências Biomédicas da Universidade de São Paulo - Av. Dr. Arnaldo, 715 - São Paulo, SP — Brasil.

* Do Departamento de Prática de Saúde Pública da Faculdade de Saúde Pública da Universidade de São Paulo — Av. Dr. Arnaldo, 715 - São Paulo, SP — Brasil. 
CANDEIAS, J.A.N, et al, - Estudo sorológico sobre a cepa A/New Jersey/8/76 em grupos populacionais brasileiros (nota prévia). Rev. Saúde públ., S. Paulo, 10:269-70, 1976.

de idade compreendida entre 9 meses e 36 meses ou mais; do grupo de indivíduos adultos normais estão em estudo 415 soros colhidos em 1974, 50 soros colhidos em 1975 e 160 soros colhidos em 1976; incluiu-se um grupo de índios da região do Xingú, cujos soros foram colhidos em 1966, 1967 e 1971, totalizando 67 amostras.

A pesquisa de anticorpos inibidores da hemaglutinação é feita segundo o método de microtitulação em placas "V" (Cooke
Engineering Co.), utilizando-se um antígeno inativado.

\section{RESULTA DOS}

No grupo de crianças encontraram-se $7.8 \%$ de soros com títulos $\geqslant 80$, percentagem que no grupo de adultos, para os soros colhidos em 1976, foi de $75 \%$; todos os soros de índios da região do Xingú apresentavam títulos $<40$.

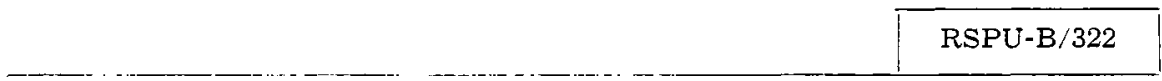

Candeia.s, J.A.N. et al. - [Serologic study of the A/New Jersey/8/76 influenza virus in Brazillan population groups (communication)]. Rev. Saúde públ., S. Paulo, 10:269-70, 1976.

SUMMARY: Serum samples from different groups of the Brazilian population were examined for their haemagglutination inhibiting antibody content to the $A /$ New Jersey $/ 8 / 76$ influenza virus with the following results: $7.8 \%$ of normal children and $75.0 \%$ of normal adults had titres of 80 or higher; in a group of Brazilian indians ail the serum samples had titres of 40 or lower.

UnITERMS: Influenza virus A/New Jersey/8/76. Serology.

\section{REFERENCIAS BIBLIOGRAFICAS}

1. CANDEIAS, J,A.N. \& PEREIRA, M.S. - The measurement by serological means of the impact of the Hong Kong/68 influenza virus on a population. Rev. Saúle públ., S. Paulo. $6: 85-8,1972$.

2. FARNIK, J. \& BRLJ, J. - An ontbreak of influenza A2 in a population with known antibody profile. $J$. infect. Dis., 116:425-8. 1966.
3. PYHÄLÄ, R, \& AHO, K. - Serum H.I. antibody and protection against influenza: A follow-up survey at community level of three epidemies caused by different H3N2-variants. Int. $J$. Epidem., 4:127-9, 1975.

Recebido para publicação em o7/06/1976 Aprovado para publicação em 14/06/1976 